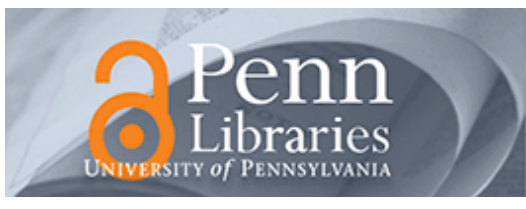

University of Pennsylvania ScholarlyCommons

6-2004

\title{
Modernism Without Modernity: The Rise of Modernist Architecture in Mexico, Brazil, and Argentina, 1890-1940
}

\author{
Mauro F. Guillen \\ University of Pennsylvania
}

Follow this and additional works at: https://repository.upenn.edu/mgmt_papers

Part of the Architectural History and Criticism Commons, and the Management Sciences and Quantitative Methods Commons

\section{Recommended Citation}

Guillen, M. F. (2004). Modernism Without Modernity: The Rise of Modernist Architecture in Mexico, Brazil, and Argentina, 1890-1940. Latin American Research Review, 39 (2), 6-34. http://dx.doi.org/10.1353/lar.2004.0032 


\title{
Modernism Without Modernity: The Rise of Modernist Architecture in Mexico, Brazil, and Argentina, 1890-1940
}

\begin{abstract}
: Why did machine-age modernist architecture diffuse to Latin America so quickly after its rise in Continental Europe during the 1910s and 1920s? Why was it a more successful movement in relatively backward Brazil and Mexico than in more affluent and industrialized Argentina? After reviewing the historical development of architectural modernism in these three countries, several explanations are tested against the comparative evidence. Standards of living, industrialization, sociopolitical upheaval, and the absence of working-class consumerism are found to be limited as explanations. As in Europe, Modernism diffused to Latin America thanks to state patronage and the professionalization of architects following an engineering model.
\end{abstract}

\section{Keywords}

Architecture, Modernist art, Architectural education, Architectural design, Architectural control, Architectural engineering, Architectural styles, Research review studies, Architectural history, Government buildings

\section{Disciplines}

Architectural History and Criticism | Management Sciences and Quantitative Methods 


\title{
MODERNISM WITHOUT MODERNITY:
}

\author{
The Rise of Modernist Architecture in Mexico, \\ Brazil, and Argentina, 1890-1940
}

\author{
Mauro F. Guillén \\ The Wharton School \\ Instituto de Empresa, Madrid
}

\begin{abstract}
Why did machine-age modernist architecture diffuse to Latin America so quickly after its rise in Continental Europe during the 1910s and 1920s? Why was it a more successful movement in relatively backward Brazil and Mexico than in more affluent and industrialized Argentina? After reviewing the historical development of architectural modernism in these three countries, several explanations are tested against the comparative evidence. Standards of living, industrialization, sociopolitical upheaval, and the absence of working-class consumerism are found to be limited as explanations. As in Europe, Modernism diffused to Latin America thanks to state patronage and the professionalization of architects following an engineering model.
\end{abstract}

During the nineteenth and early twentieth centuries, Latin American countries borrowed from Europe both the ideal of the oligarchical republic, and the architectural eclecticism and monumentalism that still characterizes the Paseo de la Reforma in Mexico City, the Avenida Central of Rio de Janeiro, and the Avenida de Mayo in Buenos Aires. French beaux-arts classicism appealed to the europhile-landed elites that ruled Mexico, Brazil, and Argentina for about one hundred years after independence in the 1810s (Gutiérrez and Viñuales 1998, 162-65). Modernism in architecture only appeared on the Latin American scene after dramatic turning points, that is, in the wake of revolution and counterrevolution, the shift from upper-class rule to the rule of the masses, the introduction of nationalist economic development programs, and in some cases, the installation of authoritarian regimes seeking legitimacy through public works.

The rise of a modernist architecture in Latin America only within a few years of its appearance in Europe was somewhat of an improbable event given the region's relative backwardness. Like Spain during the 1930s, Mexico, Brazil, and Argentina are instances of "modernism 
without modernity, ${ }^{\prime 1}$ of countries whose intellectual and cultural life was well ahead of economic and technological realities. The modernist materials par excellence-glass, steel, reinforced concrete-were not widely available in Latin America before World War II. Moreover, to the present day about 60 percent of all dwellings are erected by their own occupants (through self-help), and only 10 percent are designed by architects (Eliash and San Martín 1998, 53). Just as the classicism of turnof-the-century Latin American architecture was implemented by the Europeanizing tastes of elite architects, the rise of modernist architecture had to do with the persuasions and perseverance of a distinctively elite group of local architects influenced by European trends, with a few touches of indigenous influence (Bullrich 1969). The arrival of exiled modernist architects from Fascist and Communist Europe during the 1930s and 1940s contributed to the process. The Latin American modernists, while elitist, shared with their European counterparts a belief in social progress through good design. Latin American architects, however, did not merely imitate European developments. They actively sought to incorporate local influences, which in some cases led to the abandonment of key modernist principles.

This paper focuses on the three most dynamic countries in the region-Mexico, Brazil, and Argentina-in order of their historical development of a modernist architecture. The goal is to understand the reasons that account for the varying degrees of receptiveness to this new architectural conception. The Mexican Revolution of 1910-17 and its subsequent institutionalization eventually brought to power a group of reform-minded technocrats who saw in modernist architecture a way to improve public services and lifestyles. In Brazil, Getúlio Vargas's ideas about a "new state" (estado novo) paved the road to modernism after 1930. In Argentina the process was more protracted, although it started as early as 1916 with the election victory of the Radicals, followed by the military coup of 1930, and Juan Domingo Perón's election to the presidency in 1946. Yet the rise of modernist architecture in Latin America also had to do with the educational backgrounds and experiences of the architects themselves and their propensity to think about architecture as engineers.

\section{THE ORIGINS OF MODERNIST ARCHITECTURE}

Machine-age modernism in architecture has been studied intensely by a number of scholars (e.g., Banham 1960; Jencks 1973; Frampton 1980). The modernist architects "sought to merge aesthetic innovation with 
economic rationality" (Larson 1993, 50) by applying a mechanical metaphor to the design of houses, public buildings, schools, factories, and everyday objects. They found their inspiration in industrial buildings, Cubism and abstract painting, and new models of work organization such as scientific management or Taylorism (Guillén 1997). ${ }^{2}$ European architectural modernism insisted on the aesthetic potential of efficiency, precision, simplicity, regularity, and functionality; the production of useful and beautiful objects; the designing of buildings and artifacts that would look and be used like machines.

The aesthetic order that emerged from European modernism in architecture has been defined by its three main principles: "Emphasis upon volume-space enclosed by thin planes or surfaces as opposed to the suggestion of mass and solidity; regularity as opposed to symmetry or other kinds of obvious balance; and, lastly, dependence on the intrinsic elegance of materials, technical perfection, and fine proportions, as opposed to applied ornament" (Barr 1995, 29). European modernism in architecture represented an apotheosis of the mechanical, planning, productivity, and efficiency. As an artistic movement, modernism was rational in the sense that "architectural forms not only required rational justification, but could only be so justified if they derived their laws from science" (Collins [1965], 198). It was functional in the dual sense of making "full use of modern technology and its honest expression in design ... and [embracing] a scientific approach to human needs and uses in programming, planning and design" (Bauer 1965, 48).

This paper's analysis of Latin American architecture between 1890 and 1940 is based on the ten leading architects, each in Argentina, Brazil, and Mexico, as identified in four key histories of modernist or twentieth-century architecture, and five encyclopedias of architecture (see the Appendix). Their statements, writings, and works serve as the basis for the assessment of the vibrancy of the modernist movement in architecture in each of the three countries.

\section{MEXICO: REVOLUTION AND ARCHITECTURE}

In the thirty years following the revolution of $1910-17$, a staggering number of buildings were constructed in Mexico, including single-family homes, apartment complexes, government agencies, hospitals, movie theaters, and schools (Myers 1952). While the new regime promoted a modernist style with a certain touch of indigenous sensitivity in an attempt to turn Mexico into one of the "progressive" countries of the world, 
many architects still subscribed to the more nationalistic neo-Prehispanic and Neocolonial styles (Cetto 1961; Méndez-Vigatá 1997,61). The Mexican revolutionaries themselves were not in agreement as to what kind of architecture was best fit to achieve their social and economic goals. In fact, the Mexican Revolution was notorious for the "absence of an ideology," to paraphrase Octavio Paz (1993, 143).

\section{The Muralists and Architecture}

Architects of diverse political persuasions were enlisted by the revolutionary state, in some cases to improve working and living conditions, yet in others to glorify the revolution and the regime. Several laws were passed to promote "low-cost," "economical housing," and "workers' housing" (Gutiérrez 1998a). By far, the most activist agency was the Ministry of Education because of its control of architectural and artistic education, and also because free mass and secular instruction was at the top of the revolutionaries' agenda, in a country with a 72 percent illiteracy rate in 1921 (Meyer 1991, 208). The goal of expanding educational opportunity required the construction of hundreds of schools throughout the country. The first activist Minister of Education was José Vasconcelos (1920-24), who had spent many years in exile in the United States. He was a traditionalist with a taste for neocolonial art and architecture, and a staunch critic of things American or modern:

Mexico had a university before Boston, and libraries, museums, newspapers and a theater before New York and Philadelphia. To build is the duty of each epoch, and buildings shall be the glory of the new government. ... We did not want schools of the Swiss type... nor schools of the Chicago type [a veiled reference to modernism].... In architecture, too, we should find inspiration in our glorious past. (Quoted in Méndez-Vigatá 1997, 66-67; see also Fraser 2000, 23-32; Vasconcelos 1963)

Vasconcelos made a momentous decision early on, which was to sponsor the muralists-Diego Rivera, José Clemente Orozco, and David Alfaro Siqueiros among others-to use public facades to glorify Mexico, the revolution, and the regime's educational policies. This move had several important effects. First, it helped highlight the need to find and incorporate the local dimensions of art and architecture. In 1923 the Manifesto of the Union of Workers, Technicians, Painters, and Sculptors proclaimed that

the popular art of Mexico is the most important and the healthiest of spiritual manifestations and its native tradition the best of all traditions. . . We proclaim that all forms of aesthetic expression which are foreign or contrary to popular feeling are bourgeois and should be eliminated. (Quoted in Meyer 1991, 209)

Still, the leading muralists were influenced by the European avant-garde. Second, the privileged treatment of the muralists had the effect of 
imposing certain constraints on architects, especially the requirement to build vast wall surfaces in cement and not glass, and the added emphasis on ornamentation. ${ }^{3}$

Perhaps the most important effect of the state's sponsorship of the muralists was the architectural tastes they came to propound. Rivera, while an admirer of colonial buildings, did not agree with Vasconcelos's promotion of neocolonial and Californian architecture, and displayed an interest in the functional aspects of modernist architecture. Moreover, as director of the Central School of Plastic Arts in 1929-30, Rivera pushed very hard to introduce reforms, presenting architecture as a useful social endeavor geared towards the design of utilitarian buildings (López Rangel 1986, 15-19, 24-26). The muralists furthered a conception of art as a public enterprise at the service of the government (Paz 1993, 147). Rivera was also adamant that architecture should advance the cause of the poor (López Rangel 1986, 29).

\section{Architectural Eclecticism during the 1920 s}

Vasconcelos and other government officials sponsored architects such as Carlos Obregón Santacilia, a great-grandson of President Benito Juárez, who designed schools in Neocolonial style, various government buildings in art deco, and the Monument to the Revolution in Mexico City in a mix of California and vernacular (Mijares Bracho 1997; Fraser 2000, 32-34). Other important architects of this early period included José Villagrán García, the architect of the neocolonial National Stadium of 1929 (Méndez-Vigatá 1997, 66, 67), and Adamo Boari, a personal friend of former dictator Porfirio Díaz, who designed various "revival" public buildings during the 1910s and 1920s.

It was during the presidency of Plutarco Elías Calles (1924-28) that modernism appeared in Mexico. Obregón Santacilia and Villagrán García both started to design some modernist buildings, while continuing to build in neocolonial and even neoclassical styles. Villagrán García's gradual evolution towards modernism was key because of his prominent teaching position at the National University. As Méndez-Vigatá $(1997,77)$ has pointed out, he remained an eclectic architect, mixing beaux-arts elements (aesthetic proportions, optical corrections) with the influences of modernism (the concepts of utility and honesty in architecture). In 1927 Obregón Santacilia wrote forcefully about the need for the "Mexican architect to join the international architectural movement" (quoted in López Rangel 1986, 17). These two architects designed a now

3. It is revealing to note that the architects trained in the beaux-arts tradition admired Rivera. See the journal of the Society of Mexican Architects, El Arquitecto: Revista de Arquitectura y Artes Mexicanas 2, no. 5, (1925): 1-40; 2, no. 8 (1926): 3-36. 
famous modernist house in the San Miguel neighborhood of Mexico City, praised by Rivera because its "beauty was based on the economy of material and maximum utility ... even the electricity counter played a decorative role" (quoted in López Rangel 1986, 18).

It was also during the 1920s that Mexican engineers reasserted their roles as technocrats in the new regime (Lorey 1990). "The individual that holds the key to the future is the Engineer. Illustrious is the Engineer, and grandiose are his accomplishments. It is through the Engineer ... that the Creator is shaping the fate of humanity." ${ }^{\prime 4}$ Some engineers suggested that Mexican architects learned from Gothic so as to arrive at a logical and balanced design of the various parts of the building. They argued very strongly for a collaboration between architects and engineers. ${ }^{5}$ The Mexican engineering profession, while not as mesmerized by Taylorism as in certain European countries or in Brazil, was keenly aware of the need to incorporate scientific methods of organization, and its chosen leaders firmly believed that the engineer should be trained not only in technical subjects but also in economic and organizational ones. $^{6}$

\section{A Mexican Modernism during the 1930 s}

The truly architectural revolutionary in Mexico was Juan O'Gorman, a follower of Le Corbusier's functionalism (Luna Arroyo 1973, 94). O'Gorman's ideas were embraced by the governments of the 1930s, especially that of legendary president Lázaro Cárdenas (1934-40). $\mathrm{O}^{\prime}$ Gorman was the founder of the Union of Architects in the Fight for Socialism (1937-41), and a personal friend of Leon Trotsky's, who had left the Soviet Union for exile in Mexico. With inspiration from muralist Diego Rivera, O'Gorman found a way to resolve the perennial conflict between the past and the present by incorporating pre-Hispanic motifs (Luna Arroyo 1973). A painter and muralist, as well as architect, he was forceful in his commitment to modernism: "We should not forget that men are only rational animals, and to proceed through any medium that is not the one of maximum efficiency through minimum effort, is not to proceed rationally." In a manner reminiscent of Le Corbusier, whom he read assiduously, he proclaimed, "A house ... will be a tool, just as the automobile is becoming a tool" (quoted in Burian 1997, 127,

4. See the editorial in the inaugural issue of the journal of the National School of Engineering, Ingeniería 1 (1927): 5.

5. Ingeniería 6 (1932): 375; 8 (1934): 93.

6. See journals of the Association of Engineers and Architects of Mexico, Revista Mexicana de Ingeniería y Arquitectura 1 (1923): 46-50, 374-84; 9 (1931): 234-57; 14 (1936): $450-53$. 
129). He worked for both Obregón Santacilia and Villagrán García, and was instrumental in the creation of the School of Engineering and Architecture at the National Polytechnic Institute.

In his capacity of chief architect of the Department of School Construction of the Ministry of Education, $\mathrm{O}^{\prime}$ Gorman designed more than thirty "inexpensive schools, economically built, with durable materials, and as efficient as possible in spending the pueblo's money" (quoted in Burian 1997, 130; see also Luna Arroyo 1973, 65, 117-18). He proposed to build schools at a much lower cost than the neocolonial ones constructed during the Vasconcelos period, mostly by "eliminating all architectural style and executing constructions technically" (quoted in Fraser 2000, 47). O'Gorman also designed workers' housing, apartment buildings, and artistic studios, among them the famous contiguous though separate quarters for his personal friends Diego Rivera and Frida Kahlo (1931-32), with its Corbusian zigzagging roofs and external helicoidal stairway. Reflecting on his early years as an architect, he explained that "I didn't do architecture; I engineered buildings, using the same mental process by which one makes a dam, a bridge, a road, engineering works" (quoted in Fraser 2000, 46). In O'Gorman's view, composition was to follow a simple plan: "the spaces for circulation which served to unite and separate, the useful places for work and those for rest, separated by walls so that [each] should be efficient." He strived for an architecture that is

useful to man [sic] in a direct and precise way. The difference between a technical architect and an academic or artistic architect will be perfectly clear. The technician is useful to the majority and the academic useful to the minority.... An architecture which serves humanity, or an architecture which serves money. (Quoted in Fraser 2000, 52)

A second major figure of this period was Juan Segura, famous for his Ermita Building in Mexico City (1930-31) with its commercial space, a movie theater, and apartments, and built before Le Corbusier made the multifunctional concept famous with his Unité de Habitation. Segura had to use structural steel creatively to be able to build apartments above the ceiling of the theater. Like most other contemporary Mexican architects, he used ornaments more profusely than the modernist dogma would permit and was often classified as belonging to the art deco movement (Toca Fernández 1997). Francisco Serrano was another early designer of movie theaters, albeit more purely rationalist than Segura. ${ }^{7}$

7. See Serrano's article in Revista Mexicana de Ingeniería y Arquitectura 17 (1939): 274 76, and photographs of his Edificio-Jardín Avenida Martí in Mexico City, used by La Tolteca Portland cement company in some of its advertisements (on the back cover of the July 1933 issue). The development was owned by a company called Rentas Baratas (low rents). 
Enrique Yáñez was equally rationalist in his designs for various hospitals and healthcare centers. Another singular architect was Enrique de la Mora, whose apartment building on Calle Strasburgo in Mexico City (1934) is the paradigmatic space-saving building that looks like an ocean liner. Like the other modernist architects, Mario Pani designed hotels, apartment buildings, conservatories, hospitals, and clinics before 1940. His fame, though, is mostly due to his President Alemán Urban Housing Project in Mexico City (1949), a thoroughly Corbusian design with L-shaped apartment blocs leaving open spaces between them (Noelle Merles 1997). Like the good modernist that he was, he showed his commitment to housing the masses: "We must build for all of them. Plan! Build! Plan well! Build now!" (quoted in Eggener 2000, 38).

It is imperative to point out that Mexican "modernist" architecture deviated from the European mainstream in several respects, including the addition of murals, the use of indigenous motifs and materials, the organic design of the building to match its surroundings, and the overall emphasis on aesthetics rather than utility (Eggener 1999). Some architects-for example, Luis Barragán-were adamant in producing a peculiarly Mexican architecture using adobe, stucco, cobblestones, and unfinished wood, although they remained firmly modernist: "It has been a mistake to abandon the shelter of walls for the inclemency of large areas of glass" (Barragán, quoted in Smith 1967, 54).

Even O'Gorman eventually joined this mexicanization trend. After designing purely functionalist buildings and extolling the virtues of efficiency methods and "industrial prefabrication" during most of the 1930s, he too acknowledged the need for adding aesthetic fantasy to the purely mechanical principles of functionalism, and ultimately came to reject Le Corbusier's radical functionalism in favor of Wright's organicism (Fraser 2000, 41, 84-85; Smith 1967, 18). In the late 1930s he decided to temporarily abandon architecture to devote himself to painting. He returned to design in the mid-1940s, embracing a view of an architecture firmly rooted in its surroundings, with abundant vernacular elements, especially in the coloring and ornamentation (murals, reliefs, and sculptures) of the façade, as in the library at the National Autonomous University of Mexico built between 1950 and 1952 (Cetto 1961; Eggener 1999).

The debate between the "internationalist" architects focused on following the purest modernism, and the "nationalists" who yearned for a modern architecture adapted to Mexican realities and surroundings raged well into the 1950s, with the latter definitely gaining the upper hand. Rivera animated the debate with articles denouncing the neglect of things Mexican by those he saw as blindly following Le Corbusier without realizing that even the world's most vocal promoter of modernism had proposed an architecture blended with landscape (López Rangel 1986, 41-44, 113). Still, this "mexicanized modernism" produced 
a rational architecture that sought to cater to the needs of the population, promote the (shifting) goals of the revolution, and enhance the regime's domestic and international stature. ${ }^{8}$

\section{BRAZIL: A DISTILLED MODERNISM}

Brazilian architects produced perhaps the most refined modernist designs in the entire world, including the Casa Modernista in São Paulo (1927), the Ministry of Education and Health in Rio de Janeiro (193743), and Brasília, the new capital city. Despite the influence of European modernism - especially Le Corbusier - most of the Brazilian modernist buildings were designed and executed by a relatively small group of brilliant, locally trained architects such as Lúcio Costa and Oscar Niemeyer, who became international celebrities.

\section{The Origins of Brazilian Modernism}

Brazilian architectural modernism begins in the mid-1920s with Russian emigré Gregori Warchavchik, who arrived in São Paulo in 1923, hired by the Companhia Construtora de Santos, founded by civil engineer and entrepreneur Roberto Simonsen, Brazil's pioneer in the implementation of scientific management (Urwick 1956, 271-75). In 1925 Warchavchik published his manifesto, "Apropos of Modern Architecture," in the daily Correio da Manhã:

If we observe the machines of our times: motor cars, steamers, locomotives, etc., we find in them, along with rationality of construction, a beauty of forms and line.... A house is a machine, the technical perfection of which ensures, for instance, a rational distribution of light, heat, cold and hot water, etc. (Warchavchik [1925] 1965, 264-65)

He defended the figure of the "engineer-builder" against that of the "architect-decorator." He once wrote that "tradition is a subtle poison." "Down with absurd decoration and on with logical construction!" (quoted in Gutiérrez and Viñuales 1998, 126; Warchavchik [1925] 1965, 265 , respectively).

Warchavchik's Casa Modernista of 1927 was the first modernist building in all of Latin America. A Brazilian newspaper referred to it as a "rational house, comfortable, purely utilitarian, full of air, light, joy" (quoted in Ferraz 1965, 27). This simple, clean, geometrical design

8. The pages of the journal of the Society of Mexican Architects are filled with declarations in favor of a national style rooted in building tradition and local materials. See, in particular, El Arquitecto: Revista de Arquitectura y Artes Mexicanas 1, no. 1 (1923): 1; 2, no. 1 (1924): 1-2. Even engineers argued for a truly national style: Revista Mexicana de Ingeniería y Arquitectura 6 (1928): 396-405. 
anticipated the direction that key Brazilian architects would take in the 1930s and 1940s. Warchavchik, however, could not implement his most innovative ideas about prefabrication and standardization due to the lack of specialized contractors in Brazil. Moreover, because reinforced concrete was unavailable, he built in brick and then covered it with cement (Fraser 2000, 166). Warchavik taught or collaborated with other younger Brazilian architects, and was named by Le Corbusier as the South American representative of CIAM (Congrès Internationaux $d^{\prime}$ Architecture Moderne), thus exerting an important influence on subsequent developments.

Brazil experienced in 1930 a revolution of sorts at the hands of Getúlio Vargas, the creator of the Italian-inspired, corporatist Estado Novo. Although architectural and building activity was basically put on hold for a few years, the new regime promoted industrialization and the rationalization of work. Brazilian engineers had started to discuss Taylorism in the 1920s, but it was not until the 1930s that the first systematic attempts at implementation took place. The Vargas regime was enthusiastic about scientific management as a tool to achieve not just economic growth in the private sector but also improved administrative practices in the public sector. Experiments with Taylorism proliferated, and links developed between industrialists and modernist designers. ${ }^{9}$

In 1935 the regime organized a competition for one of its landmark projects, the Ministry of Health and Education in the country's capital, Rio de Janeiro. A team of young Brazilian architects led by Lúcio Costa and Oscar Niemeyer, and also including Jorge Moreira and Affonso Eduardo Reidy, won with a stunningly modernist design. Le Corbusier-who had first visited Brazil in 1929-was invited to provide advice before construction began. When the building was finished in 1943 after six years of work, the result could not have been more impressive: a large bloc of reinforced concrete built on 30-feet high pilotis, sun breakers on the north side and glass on the south side (Rio being in the Southern Hemisphere), and a rooftop garden. The design occupied an entire city block, leaving room for a plaza. The building itself included separate areas for civil servants and for the public (Ficher and Milan Acayaba 1982; Fraser 2000, 150-64; Bullrich $1969,22-4)$. Art historians have labeled it the "first realization of a building type of which Le Corbusier had been thinking for some timethe Cartesian skyscraper for administrative purposes" (Benevolo 1977,

9. See Saenz Leme 1978; Guzzo Decca 1987; ROC 1932; Urwick 1956, 256-58, 271-78; Weinstein 1990. See also the official journal of the Brazilian Institute for the Scientific Management of Work, IDORT 3, no. 26 (February 1934): 32-35, 40-42; 3, no. 31 (May 1934): 145-48; 3, no. 34 (October 1934): 217-25, 233-37; 3, no. 35 (November 1934): 25258; 3, no. 36 (December 1934): 276-79. 
750). American contemporaries were so taken by it that the Museum of Modern Art in New York decided to dispatch a delegation to visit the building. The catalogue of the MoMA's 1943 exhibition, "Brazil Builds," put it succinctly: "While Federal classic in Washington, Royal Academy archaeology in London, and Nazi classic in Munich are still triumphant . . . Rio can boast of the most beautiful government building in the Western hemisphere" (Goodwin 1943, 92).

The Ministry building was just the beginning of what would be a long series of outstanding modernist designs by Brazilian architects (Deckker 2001). At around the same time, Marcelo and Milton Roberto designed the ABI building (Associação Brasileira de Imprensa), also in Rio (Xavier, Britto, and Nobre 1991, 40). In 1937 Marcelo and Mauricio Roberto won the competition for the Santos Dumont Airport terminal in Rio, which was completed in 1944, a building dominated by twostory high pilotis. Meanwhile, Costa and Niemeyer designed several other landmark buildings and projects, together or individually. Most fatefully, Niemeyer received several commissions from the mayor of Belo Horizonte, Juscelino Kubitschek, later to become the president who would commit to building Brasília. While the government's building priorities did not include affordable housing for workers, some architects devoted much of their careers to housing of various kinds, always emphasizing simple designs, functionalism, durable materials, and the comforts of modern appliances. These included Oswaldo Bratke, Bruno Levi, and Affonso Eduardo Reidy.

\section{Brasília}

If Brazilian modernism first acquired international fame with the Ministry of Education and Health Building, the design and construction of Brasília, the new capital city meant to help colonize the country's vast interior and muster in a new era of progress, demonstrated to the world the intellectual maturity of Brazilian modernist architecture. It was supposed to be, in the words of President Kubitschek, the "anticipation of the future," the incarnation of the "national will" to develop Brazil's economy and territory, the "point of convergence of all the interests of the nation" (quoted in Durand 1991, 76).

Although the design and construction of Brasília took place after 1940, the brightest Brazilian architects of the modernist generation of the 1930s participated in the many aspects of the overall project. Lúcio Costa supplied the overall pilot plan in 1956, a thoroughly Corbusian arrangement, with separate areas for housing, work, recreation, and traffic. "As a city dominated by its system of highways for cars, and shaped like an aeroplane, it neatly combines two key images of modernity" (Fraser 2000, 225). In fact, the pilot plan contains myriad references to the automobile 
(Costa 1991). Costa's design for the residential areas consisted of communal superblocks (superquadras) that emphasized collective life rather than private property, and intended to avoid "any undue and undesired stratification of society." Brasília was to be "an exemplar, or enclave, or beachhead, or blueprint of radiating change which creates a new society on the basis of the values that motivate its design," i.e., equality, standardization, and progress (quoted in Holston 1989, 76-77; Costa 1991, 28-30). In fact, it became five cities in one, four of them not planned, and it failed to instill new living and social habits (Holston 1989; Gutiérrez 1998a, 27; Fraser 2000, 240-41; Ludwig 1980).

\section{ARGENTINA: THE LAND OF ECLECTICISM}

Until 1916 Argentina was a liberal republic ruled by a landed oligarchy. The country was one of the ten richest in the world thanks to staggering exports of agricultural commodities and livestock. The ruling elite imported the best neoclassical and academic European architecture in an attempt to emulate its counterparts in the Old World, giving Buenos Aires, the provincial capitals, the fashionable summer resorts, and the estancias a distinctively European outlook (Ortiz et al. 1968; Bullrich 1963). Visiting Buenos Aires in 1909, writer Anatole France was stunned by the National Congress building, designed by the Italian architect Victor Meano, which he described as

a mix containing Italian salad, with Greek, Roman and French ingredients. ... On top of the Louvre colonnade they put the Parthenon; on the Parthenon they managed to place the Pantheon, and then they sprinkled the cake with allegories, statues, balustrades, and terraces. (Quoted in Gutiérrez and Viñuales 1998, 122)

The Congress dominates the background of the exquisitely segnorial Avenida de Mayo of 1882-94, modeled after the Boulevard Hausmann in Paris.

There was, to be sure, another side to the Argentine-built environment. Much of the infrastructure required to sustain the foreign trade boom was extremely functional in design and outlook. Massive grain silos, railway halls, harbor facilities, bridges, and marketplaces were built between 1880 and 1910 (Gazaneo and Scarone 1984; Liernur 2000; De Paula and Gómez 1984). But, as in the United States, the world of engineering and production was far apart from the world of architecture, and Argentine architects did not manage to bridge the gap between the two, although several tried very hard. Moreover, scientific management and Fordism were not debated or implemented widely until the 1940s. Efforts at work rationalization were random and episodic rather than systematic, in sharp contrast with developments in Brazil and Mexico (James 1981; Kabat 1999; Dorfman 1995; Liernur 2000, 170). 


\section{Between Academicism and Nationalism}

A unique aspect of Argentine architecture during the first half of the century was the attempt by several prominent academic architectstrue believers in the aesthetic and technical superiority of cosmpolitan, Parisian architecture-to arrive at a national style. The key figure was Alejandro Christophersen, born in Spain of Norwegian parents. He was the founder of the School of Architecture at the University of Buenos Aires in 1901, which he modeled after the École des Beaux-Arts. He most famously designed in 1906 the residences of the Anchorena family, nowadays the Ministry of Foreign Affairs, in the most splendid French neoclassicist style. The complex includes three separate residences around a cour d'honneur. Christophersen designed dozens of residences, urban and rural, churches, hotels, and bank offices. In the 1910s and 1920s he toyed with the idea of a national architecture, which he sought to find in the revival of neocolonialism and the so-called "mission style." He wrote articles and books on this subject, extolling John Ruskin's ideas about workmanship (Crispiani 1999).

Another attempt at renovation came from the Argentine disciples of the Catalan modernists. Julián García Núñez studied in Barcelona with Gaudí and Domènech i Montaner. He returned to Argentina in 1903 and introduced a combination of Catalan modernisme (mostly art nouveau) with the more linear German Jugendstil. He designed hospitals, residences, offices, and churches. Other younger architects-Martín Noel, Ángel Guido-continued in this tradition of combining several strands of proto-modern European trends well into the 1920s and 1930s, with the innovation of attempting to merge them with vernacular styles, including pre-Columbian, colonial, and Californian influences (Liernur 2000, 114-38). In fact, Noel pioneered the "Nationalist Restoration" movement, advocating the Spanish colonial style he saw in Bolivia and Peru as the main source of architectural ideas for all of Latin America, including Argentina. He argued that "the nationalist ideal, based on an intimate relationship between history and architecture, far from detracting from a local art ... would become ... a unified and balanced aesthetic" (quoted in Gutiérrez 1984a, 151).

Like Noel, Guido developed a taste for the vernacular while doing restoration work. In 1927 he characterized Le Corbusier as "confusing, capricious, and superficial," and asserted that "standardization turns architecture into an ignoble undertaking and not an art; in other words, it turns the architect into a trafficant or commissioner as opposed to an artist" (quoted in Gutiérrez 1984a, 152). Even foreign-born engineersturned-architects who moved to Argentina-like Hungary's Juan Kronfuss - embraced the attempt to produce a national style rooted in local traditions and accomplishments (De Paula 1984). 


\section{A Frustrated Modernism}

During the late 1920s Christophersen engaged in a rather heated debate with the Argentine modernists, especially with architect Alberto Prebisch, who had graduated from the Buenos Aires School of Architecture in 1921 (Christophersen [1927] 1999; Prebisch 1927). Prebisch embarked on a European tour, coming to the realization that he had learned all there was to be learned about academic architecture. He came in touch with the Parisian avant-garde, and with the writings of Le Corbusier. Upon his return to Argentina in 1924 he won the competition for the Sugar City in his native province of Tucumán, in the northern part of the country. Inspired by Tony Garnier's industrial city, Prebisch also included motifs from colonial arquitecture, although the design was eminently modernist in conception and execution (CEDODAL 1999, 59-72). He also designed marketplaces and hospitals with the same sober, measured approach to the incorporation of neocolonial influences so as to make modernism more congruent with its surroundings (Rodríguez Leirado 2001). In 1933-34 Prebisch traveled to the United States, where he absorbed Wright's organicist architecture, and saw first-hand the achievements of industrial engineering and town planning. His subsequent designs marked a milestone in Argentine architecture, including the Obelisk (1936) and the Gran Rex movie theater (1937), located within a couple hundred yards from each other at the heart of a remodeled downtown Buenos Aires. The Rex was a landmark in the simplication of design and in the use of glass to provide a continuity between the street and the foyer inside.

While Prebisch was somewhat eclectic in his combination of academic, colonial, and rationalist themes, other Argentine architects pursued a more firmly modernist path starting in the late 1920s. Antonio Ubaldo Vilar stunned his contemporaries with his technically impeccable though aesthetically dull Banco Popular Argentino of 1926. Vilar collaborated on many projects with the study of Sánchez, Lagos y de la Torre, which designed the Kavanagh skyscraper in Buenos Aries (1934), at the time the tallest reinforced concrete structure in the world (Gutiérrez 1998a, 22). Vilar was also active in the area of low-cost industrialized housing, and in the design of rational service stations for the Argentine Automobile Club (Ortiz and Gutiérrez 1973, 18). But most of the modernist apartment buildings were designed not for the working class or the poor, but for the affluent (Liernur 2000, 196-207; CEDODAL 1999, 56-57).

More concerned with aesthetics was Spanish-born Antonio Bonet. After spending two years with Le Corbusier, he moved to Buenos Aires just before the start of World War II. He was a co-founder, with Jorge Ferrari Hardoy (who also worked for Corbu) and others, of the Grupo Austral (1938-41), Argentina's avant-garde modernist group. His most 
important designs were several summer resorts in Uruguay and Argentina. After getting frustrated with Perón's anachronistic views of architecture, he decided to accept commissions in Spain, beginning in 1949. Together with Juan Kurchan and Hardoy, Bonet designed in 1939 the famous steel-and-leather B.K.F. butterfly-shaped chair, which was widely publicized in design magazines around the world, and became part of the MoMA's permanent collection. Another key modernist architect was Mario Roberto Álvarez, a follower of Mies van der Rohe in his simplified designs, careful attention to the functions of buildings, and the mechanical equipment in them.

While these and other architects were struggling to introduce some of the most important principles of modernism, the Argentine government promoted a variety of styles. General Perón, who ruled between 1946 and 1955, animated nationalist fervor by commissioning buildings in neocolonial style, while turning to neoclassical for the buildings signaling major accomplishments of his regime, for example, the Banco de la Nación Argentina, the Banco Hipotecario, and, most importantly, the Fundación Eva Perón. He only reached to a veiled modernism in the case of minor public buildings. Architecturally, the Perón years were in fact a continuation of the 1930s and early 1940s in that most public buildings were historicist and neoclassical, in what has been referred to by historians as the "imperial architecture" for its attempt to present the Argentine state in the most grandiose and monumental way (Ortiz 1984, 192; Gutiérrez 1984b; Gorelik 1987). The President of the Central Society of Architects, Bartolomé Repetto, put it succinctly in 1941: "We are taken by the unstoppable and all-powerful certainty that our homeland is destined to grandeur and splendor" (quoted by Ortiz and Gutiérrez 1973, 24).

By the late 1940s, and despite the achievements of the 1930s, modernism in Argentina appeared to be "isolated and in crisis" (Bullrich 1963, 23). Architects searched for their roots and attempted to shape modernism to local needs. For instance, members of the Grupo Austral declared in 1939 that

the architect, using the facile and superficial motifs of modernism, has created a new academy, sheltering the mediocre, producing the 'modern style' ... Functional architecture, with its aesthetic prejudices and puerile intransigence, arrived at intellectual and dehumanizing solutions because it misinterpreted the idea of the 'machine for living' and ignored individual psychology. (Quoted in Bullrich 1963, 23)

In fact, the mainstream of Argentine architecture reacted against international influence, especially against machine-age modernism (Ortiz and Gutiérrez 1973; Sonderéguer 1986). It is perhaps ironic that the yearning for an architecture rooted in local tradition was felt so strongly in Argentina, a country in which the pre-Columbian and colonial legacies were much more limited than in Brazil or especially Mexico. Argentina 
was certainly open to foreign influences ranging from neoclassicism to art nouveau to modernism, but in the end it proved to be much less welcoming than either Mexico or Brazil.

\section{WHAT EXPLAINS LATIN AMERICAN ARCHITECTURAL MODERNISM?}

The rise of a modernist architecture rooted in the machine age has preoccupied numerous architectural historians and social scientists. The vast literature on modernism, however, contains surprisingly few comparative analyses of the different causes that may have produced such a distinct and influential artistic movement. Moreover, few studies have considered evidence from Latin America.

Available explanations of the emergence of architectural modernism make different assumptions about the role of architecture in society, and result in different arguments. For many historians, architecture is primarily shaped by material conditions, and thus modernism in architecture needs to be seen as an outgrowth of machine-based industrialization, of the new forms, materials and techniques of the industrial age (Hitchcock and Johnson [1932] 1995; Pevsner [1936] 1960; Giedion [1941, 1948]; Hitchcock [1958]; Tafuri [1973]; Frampton [1980]). Some historians focused on industrialization as an explanation also point out that it was not just the material conditions created by industrialization that matter but also the intellectual ideas that came hand in hand with it, including functionalism and rationalism (Collins [1965]; Zevi [1973]; Banham 1980). A second main group of architectural historians, by contrast, assumes that architecture responds to social and political conditions, so that modernism was the result of a concern for social reform in the wake of the dislocation caused by industrialization (Jencks 1973; Benevolo [1960]).

Social scientists have proposed a third way of looking at architecture, one emphasizing the tastes and preferences of those who pay for it or use it. Their argument is that modernism flourished only when architects enjoyed a measure of autonomy from the immediate pressures of the mass consumption market, which tended to produce kitsch as opposed to streamlined modernist design (Bourdieu 1984, 1996; Adorno 1994, 1997; Gartman 2000). In a related argument, other social scientists, and some architectural historians, have highlighted the patronage of industrial firms and the state as direct causes of architectural Modernism (Campbell 1978; Lane 1985; DiMaggio 1991; Nolan 1994). Finally, a last group of social scientists assumes that architecture is primarily to be seen as a profession based on a claim to some body of abstract knowledge. Modernism in architecture is supposed to be based on the worldview and techniques that stem from an engineering model. Accordingly, modernism emerged to the extent that engineering influenced 
the education, training, and professionalization of architecture (Kadushin 1976; Guillén 1997; Pfammatter 2000).

Industrialization. It seems clear that modernism did not necessarily emerge from the most developed or industrialized countries in either Europe or the Americas; nor did it necessarily fail in the poorer areas. Argentina (per capita income of $\$ 4,367$ in 1929) was much richer and in many ways more industrialized than either Mexico $(\$ 1,489)$ or Brazil $(\$ 1,106)$, and yet architectural modernism was stronger as a movement in the latter two countries (see the figures in Maddison 1995). The lack of a positive correlation between economic development and machineage modernism is also the case when examining specific industries. The two quintessential modernist industries that captured the imagination of the modernist architects-railways and automobiles-were more developed in Argentina than in either Mexico or Brazil. Similarly, production of the two key materials used by modernist architects-steel and cement-also fails to explain differences in the rise of modernism. Per capita production of steel and cement was lower in Brazil and Mexico than in Argentina (Banks 2001). As mentioned above, architects in Brazil were constrained by the lack of cement, but this did not prevent them from designing and constructing modernist buildings. Thus, architectural Modernism was not simply a function of economic development, miles of railway track, automobiles, steel or cement. Neither did modernism emerge more strongly in countries with a higher degree of urbanization: In 1929 about 25 percent of the population in Argentina lived in cities greater than 100,000, compared to 12 percent in Brazil and 8 in Mexico (Banks 2001).

Sociopolitical Upheaval. A second contextual factor frequently linked to the rise of a modernist architecture is the occurrence of sociopolitical unrest. Social and political discontinuities may have created conditions conducive to modernist architecture because such crises generate demand for low-cost buildings and also offer opportunities to overthrow the established artistic order. While sociopolitical upheaval helps explain developments in certain European countries like Germany, Italy or Russia because it enabled architects to experiment with new ideas, the Latin American cases serve as a reminder that political change, while conducive to architectural experimentation and renewal, may not necessarily help bring about modernism. Thus, in Mexico the initial thrust for architectural reform during the early post-revolutionary years came from the adoption of neocolonial and vernacular influences, rather than from international modernism. Likewise, Peronism in Argentina, while revolutionary in many respects, proved to be old-fashioned in terms of architectural policy. Modernism flourished in Brazil to a greater extent 
than in either Argentina or Mexico, and yet political changes during the 1920 s and 1930s were less strident.

Class Dynamics and Artistic Production. The argument that the absence of a class of workers-consumers enabled architects to experiment with new artistic possibilities that might lead to Modernism does not seem to explain the patterns found in Latin America. The degree of development of working-class consumerism was strikingly similar back in the 1920s and 1930s in Argentina, Brazil and Mexico, and yet modernism failed in the former country but developed in the two latter ones.

\section{AN ACCOUNT BASED ON SPONSORSHIP AND PROFESSIONALIZATION}

Contrary to the tenets of many architectural historians and social scientists, industrialization, sociopolitical upheaval, or class dynamics cannot fully explain the emergence of modernist architecture in either Europe or Latin America (Guillén 1997). An explanation based on sponsorship and professionalization seems to work much better. The rise of modernism in architecture was intimately linked to the professionalization of architecture, which resulted from struggles between and within professional groups, that is, engineers versus architects, and academic versus modernist architects. Each group attempted to establish its claims to aesthetic authority and expert knowledge about architecture and building, with varying outcomes from country to country. Architecture became a separate profession late in the nineteenth or early twentieth century, depending on the country, and always after engineering had consolidated itself as a profession linked to the world of industry and public works. Until then, most builders were artisans or craftsmen with no formal training in their trade, while master architects tended to be educated in the beaux-arts tradition and have little, if any, contact with industry or knowledge about building methods and the construction business. The professionalization of architecture took place between 1890 and 1940 in the midst of a great debate about whether it was a decorative art or an application of technology, and whether the architect should remain an individualist, bohemian, and detached artist or become involved in all aspects of the construction industry. Furthermore, the old conception of architecture as a decorative art assumed that only the state, the upper class, and perhaps the church were legitimate patrons, while industry was considered an unworthy source of architectural commissions.

New Roles in Sponsorship. While changes in sponsorship for architectural projects were crucial to the development of modernism, no single type of sponsor predominated in all countries in which modernist architecture succeeded. Consider the state. In Germany, the Soviet Union, 
Brazil, Mexico, and, to a somewhat lesser extent, Italy, modernism developed during a period of rising state involvement in industry and art. In France, by contrast, state support for modernist projects and artistic experimentation was far less sustained, but modernism nonetheless developed, albeit more slowly. This argument, however, helps to explain the failed modernist cases of Argentina and Britain, where the state played no role as a sponsor of architecture until after World War II. By 1952 the Argentine state was spending nearly six percent of its gross domestic product on housing, with many of the projects sponsored by the Fundación Eva Perón. However, the increasing involvement of the state in the economy did not translate into a coherent architectural policy. As a result, various styles were promoted, even simultaneously (Eliash and San Martín 1998, 56-57; de Larrañaga and Petrina 1987). In contrast to Europe, industry played a more modest role in Latin America, where state agencies (education, public works) were the key actors, especially in Brazil and Mexico. Only a few architects, like Warchavchik, were sponsored by industrialists. He referred to them as the Medicis or the Louises of modern architecture (Warchavchik 1965, 39-D).

Engineering and the Professionalization of Architecture. In Europe, modernist architecture emerged earlier and most forcefully in countries in which at least some architects were trained together with engineers in the same schools, for example, Germany, Italy, and Russia. In other countries, the beaux-arts tradition (France, Spain) or the disorganization of professional training made it difficult for architects to depart from historical styles (Guillén 1997). In Latin America, the education of architects started in the academic tradition of the beaux-arts, but it evolved differently by country, with Mexico and Brazil gradually gravitating towards engineering and modernism, while Argentina followed a haphazard path.

The training of Mexican architects started in 1781 following the academic French and Spanish models. In 1857 a new curriculum of Italian influence was introduced, which integrated the study of engineering and architecture. In fact, graduates were called "engineer-architects." While other reforms took place during the Juárez presidency, architects continued to be trained at the School of Engineering until 1910, when the teaching of architecture was transferred to the School of Fine Arts, modeled after the Parisian example. ${ }^{10}$ The Mexican Revolution and the coming of age of the generation of architects nurtured by the new regime created the conditions for a gradual rapprochement with technical subjects and modernism. The Association of Engineers and Architects

10. See the journal of the Society of Mexican Architects, El Arquitecto: Revista de Arquitectura y Artes Mexicanas 1, no. 3 (1923): 1-4. 
proved to be better organized, better connected, and more influential than the Society of Mexican Architects, whose members were fine arts graduates. The engineers argued that architectural education and design practices should incorporate a more technical approach, and invited architects to work together with them. They insisted on the importance of applying scientific methods (including those of Taylorism), giving engineers a key planning and social role, and involving the state in housing and urban projects. Some engineers explicitly endorsed "modern architecture" because of its "elegance and sobriety." Engineers had established professional accreditation examinations earlier than architects. ${ }^{11}$ Meanwhile, architects trained in the beaux-arts tradition were busy cataloguing and analyzing Mexican pre-Columbian and colonial architecture, emphasizing that "feeling" should guide design and yearning for a national Mexican style. ${ }^{12}$

José Villagrán García initiated the effort to align architectural education with the new modern functionalism in 1923, at a time when many of Mexico's most influential architects of the mid-century were being trained. In his class on the theory of architecture at the School of Fine Arts, Villagrán García would lecture on "utilitarianism, mechanical stability, and architectural beauty" and highlight the architect's "social role" (Alva Martínez 1983, 61). New educational institutions were created to train architects following the precepts of modernism, like the School of Construction Technicians of the National Polytechnic Institute, headed by Juan O'Gorman (Fraser 2000, 50-51). These events took place in the midst of educational and economic reforms that placed a great value on engineering and technology (Lorey 1990).

In Brazil the beaux-arts tradition had a long history by Latin American standards. Rio de Janeiro's School of Fine Arts was originally founded in 1826 by a government-sponsored team of French artists. Few architects graduated from it until the early twentieth century. Meanwhile, industrial and urban growth prepared the ground for the creation of as many as ten engineering schools that granted the degree of "engineerarchitect," which produced many more graduates than the fine arts schools. The critical moment came in the late 1920s, when a movement of neocolonialist architecture emerged at the National School of Fine Arts in Rio as a nationalistic response to the proliferation of eclectic styles.

12. El Arquitecto: Revista de Arquitectura y Artes Mexicanas 1, no. 1 (1923): 1; 1, no. 3 (1923): $1-4 ; 1$, no. 4 (1923): 9-10; 2 , no. 1 (1924): $1-2$. Only one article published during the 1920s, written by Alfonso Pallares, recommended including more scientific and technical subjects in architectural curriculum: 2, no. 4 (1925): 4-10. 
Le Corbusier's visit in 1929 gave impetus to the reform movement and pointed it in the direction of modernism. Simultaneously, the new Vargas regime of 1930 placed a strong emphasis on technocracy and corporatism, providing modernists with an institutional opportunity with the creation of the Ministry of Education and Health in 1931, headed by a politician well attuned to the avant-garde. Also in 1931, Lúcio Costa was appointed director of the National School of Fine Arts, to the delight of the students. The faculty's opposition, however, was stiff, and he held his post for a mere nine months (Durand 1991; Ferraz 1965, 35-37). He succeeded, though, in planting the seeds for a departure from academicism, that would benefit several of the younger influential Brazilian architects trained at the Rio school during the early 1930s (Moreira, Niemeyer, Reidy, and the Roberto brothers). Of the other architects included in the Appendix, Bratke attended engineering school, and Levi and Warchavchik were educated in Italy before they moved to Brazil.

While in Mexico and Brazil the main precepts of modernism had become part of the curriculum by 1930, the situation in Argentina was rather different. The most influential Argentine architects of the turn of the century were trained in Europe in the beaux-arts tradition. The first degree in architecture was offered at the University of Buenos Aires in 1878 , and most of the curriculum was the same as for civil engineering. An Argentine-trained architect was "simply a civil engineer cut short" (De Paula 1984). In 1901 architectural education was separated from engineering with the creation of a School of Architecture in Buenos Aires firmly rooted in the beaux-arts tradition, where the next two generations of Argentine architects received their training. New subjects added to the curriculum included decorative composition, hygiene, and architectural history (Liernur 2000, 112-14). No innovative school of architecture emerged as an alternative institution to the traditional beaux-arts education. Engineering, itself an underdeveloped profession, exerted a minuscule impact on architectural education. Most telling of all, the number of practicing, certified architects grew faster between 1895 and 1914 than that of engineers (Liernur 2000, 38-42). If any of the ten most influential Argentine architects listed in the Appendix were influenced by engineering in any meaningful way (Prebisch, for example), it was not during their time at school.

\section{CONCLUSION}

Modernist architecture diffused to Latin America just shortly after its inception in Europe, first to Mexico in the 1920s and then to Brazil in the 1930s. In Argentina, its development was more haphazard and less complete. A key factor was the training of architects. In Mexico and Brazil the precepts of modernism were introduced into the architecture 
curriculum in the late 1920s just in time to influence the new generation of architects that started to design and build before World War II. By contrast, modernism was slow to emerge in Argentina precisely because of the lack of such an influence of engineering on architectural education. The state was also an important factor, especially in Mexico and Brazil, and sociopolitical upheaval certainly facilitated change, although in Mexico it did not automatically lead to an architecture based on utilitarian principles.

This paper has highlighted that prior to 1940 modernist architecture in Latin America developed in the absence of a modern economy and industry, although it did tend to emerge in the most developed and urban enclaves of each country (Mexico City, São Paulo, Rio, Buenos Aires). To be sure, World War II and the systematic efforts at import-substitution industrialization that took place during the 1950s and 1960s inaugurated an entirely new period in Latin American architectural history, one in which urbanization and massification grew rapidly, while the basic postulates of international modernism were modified and even abandoned (Bullrich 1969; Gutiérrez 1998a). In Mexico, the 1950s marked the return to local and cultural specificity, much in line with the organic architecture of Frank Lloyd Wright, with its emphasis on the integration between building and site (Eggener 1999). Brazilian modernism took on a life of its own, adopting a distinctively expressionist character, the socalled "free-form modernism" (Deckker 2001). In Argentina some architects reverted back to neoclassicism while others adopted extreme versions of modernism, sometimes referred to as brutalism because of the use of masses of cement (Liernur 2000). The reception of modernist architecture in Latin America thus corroborates the general pattern that foreign influences, while attractive at first, are ultimately refracted through the lens of local peculiarities and institutions.

\section{REFERENCES}

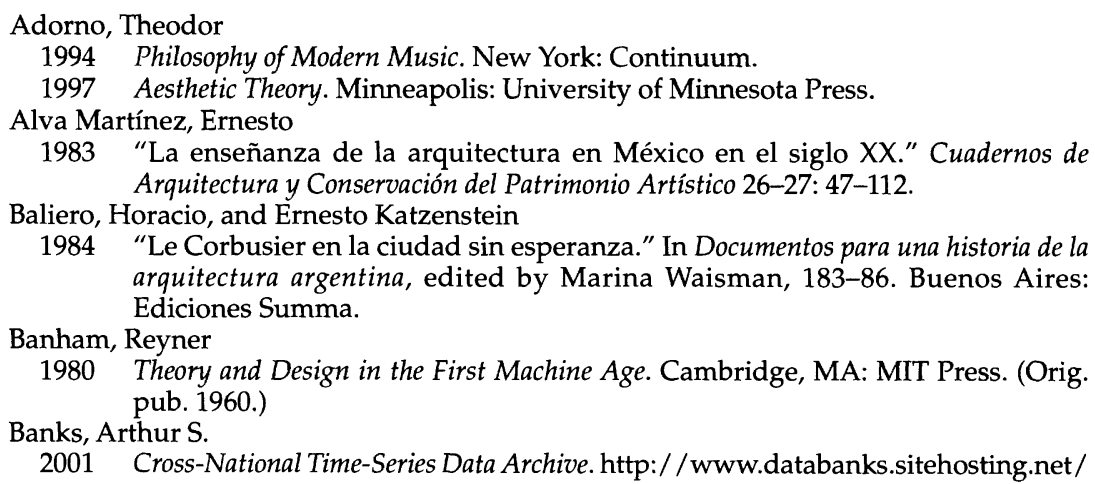


Barr, Alfred H., Jr.

1995 "Preface." In The International Style, by Henry-Russell Hitchcock and Philip Johnson, 27-32. New York: W.W. Norton.

Benevolo, Leonardo

1977 History of Modern Architecture. Cambridge, MA: MIT Press. (Orig. pub. 1960.)

Bourdieu, Pierre

1984 Distinction: A Social Critique of the Judgment of Taste. Cambridge, MA: Harvard University Press.

1996 The Rules of Art: Genesis and Structure of the Literary Field. Stanford, CA: Stanford University Press.

Bullrich, Francisco

1963 Arquitectura argentina contemporánea. Buenos Aires: Nueva Visión.

1969 New Directions in Latin American Architecture. New York: George Braziller.

Burian, Edward R.

1997 "The Architecture of Juan O'Gorman: Dichotomy and Drift." In Modernity and the Architecture of Mexico, edited by Edward R. Burian, 127-49. Austin, TX: University of Texas Press.

CEDODAL (Centro de Documentación de Arquitectura Latinoamericana)

1999 Alberto Prebisch: Una vanguardia con tradición. Buenos Aires: CEDODAL.

Cetto, Max L.

1961 Modernist Architecture in Mexico. Arquitectura moderna en México. New York: Praeger.

Christophersen, Alejandro

1999 "Un rato de charla con un futurista." Revista de arquitectura 77 (May). Reprinted in Alberto Prebisch: Una vanguardia con tradición, 175-77. Buenos Aires: CEDOAL. http://www.almagen.com.ar/sitio/seccion/arquitectura/prebisch/ disputal.html.(Orig. pub. 1927.)

Collins, Peter

1998 Changing Ideals in Architecture. Montreal and Kingston: McGill-Queen's Univer-

Costa, Lúcio sity Press. (Orig. pub. 1965.)

1991 Relatório do plano piloto de Brasília. Brasília: Governo do Distrito Federal.

Crispiani, Alejandro

1999 "Alejandro Christophersen y el desarrollo del eclecticismo en la Argentina." Arquitectura en línea. http:/ / www.arquitectura.com/historia/protag/christoph/ christoph.asp.

Curtis, William J. R.

1996 Modern Architecture since 1900. London: Phaidon Press.

De Larrañaga, María Isabel, and Alberto Petrina

1987 "Arquitectura de masas en la Argentina (1945-1955): Hacia la búsqueda de una expresión propia." Anales del Instituto de Arte Americano e Investigaciones Estéticas 25:107-15. (Orig. pub. 1982.)

De Paula, Alberto S.J.

1984 "Kronfuss en la universidad y 'lo nacional' en el diseño arquitectónico." In Documentos para una historia de la arquitectura argentina, edited by Marina Waisman, 153-54. Buenos Aires: Ediciones Summa.

De Paula, Alberto S.J., and Raúl Arnaldo Gómez

1984 "El Art Déco: Orígenes y proyecciones en nuestro país." In Documentos para una historia de la arquitectura argentina, edited by Marina Waisman, 163-66. Buenos Aires: Ediciones Summa.

Deckker, Zilah Quezado

2001 Brazil Built: The Architecture of the Modern Movement in Brazil. London: Spon Press.

Dorfman, Adolfo

1995 "Taylorismo y Fordismo en la industria argentina de los '30 y '40." Realidad Económica 132 (May): 87-96.

Durand, Jose Carlos

1991 "Political Negotiation and the Renovation of Architecture: Le Corbusier in Brazil." Actes de la Recherche en Sciences Sociales 88 (June): 61-77. 
Eggener, Keith L.

1999 "Towards an Organic Architecture in Mexico." In Frank Lloyd Wright: Europe and Beyond, edited by Anthony Alofsin, 166-83. Berkeley, CA: University of California Press.

2000 "Contrasting Images of Indentity in the Post-War Mexican Architecture of Luis Barragán and Juan O'Gorman." Journal of Latin American Cultural Studies 9, no. 1: $27-45$.

Eliash, Humberto, and Eduardo San Martín

1998 "La vivienda social y la construcción de la periferia urbana en América Latina." In Arquitectura latinoamericana en el siglo XX, edited by Ramón Gutiérrez, 53-64. Barcelona: Lunwerg Editores.

Ferraz, Geraldo

1965 Warchavchik e a introdução da nova arquitetura no Brasil: 1925 a 1940. São Paulo: Museu de Arte de São Paulo.

Ficher, Sylvia, and Marlene Milan Acayaba

1982 Arquitetura moderna brasileira. São Paulo: Projeto.

Frampton, Kenneth

1992 Modern Architecture: A Critical History. London: Thames and Hudson. (Orig. pub. 1980.)

Fraser, Valerie

2000 Building the New World: Studies in the Modern Architecture of Latin America, 19301960. London: Verso.

Gartman, David

2000 "Why Modern Architecture Emerged in Europe, not in America: The New Class and the Aesthetics of Technology." Theory, Culture \& Society 17, no. 5: 75-96.

Gazaneo, Jorge O., and Mabel M. Scarone

1984 "Arquitectura de la revolución industrial en la Argentina." In Documentos para una historia de la arquitectura argentina, edited by Marina Waisman, 113-16. Buenos Aires: Ediciones Summa.

Giedion, Siegfried

1982 Space, Time, and Architecture: The Growth of a New Tradition. Cambridge, MA: Harvard University Press.

1969 Mechanization Takes Command. New York: W. W. Norton. (Orig. pub. 1948.)

Goodwin, Philip L.

1943 Brazil Builds: Architecture New and Old, 1652-1942. New York: Museum of Modern Art.

Gorelik, Adrián

1987 "La arquitectura de YPF, 1934-1943: Notas para una interpretación de las relaciones entre Estado, modernidad e identidad en la arquitectura argentina de los años 30." Anales del Instituto de Arte Americano e Investigaciones Estéticas 25:97-106.

Guillén, Mauro F.

1997 "Scientific Management's Lost Aesthetic: Architecture, Organization, and the Taylorized Beauty of the Mechanical." Administrative Science Quarterly 42, no. 4 (December): 682-715.

Gutiérrez, Ramón

1984a "Una nueva propuesta: El renacimiento colonial." In Documentos para una historia de la arquitectura argentina, edited by Marina Waisman, 151-54. Buenos Aires: Ediciones Summa.

1984b "La arquitectura imperial." In Documentos para una historia de la arquitectura argentina, edited by Marina Waisman, 205-6. Buenos Aires: Ediciones Summa.

1998a "Arquitectura latinoamericana: Haciendo camino al andar." In Arquitectura latinoamericana en el siglo XX, edited by Ramón Gutiérrez, 17-39. Barcelona: Lunwerg Editores.

1998b "Diccionario enciclopédico." In Arquitectura latinoamericana en el siglo XX, edited by Ramón Gutiérrez, 187-440. Barcelona: Lunwerg Editores.

Gutiérrez, Ramón, and Graciela M. Viñuales

1998 "Grances Voces." In Arquitectura latinoamericana en el siglo XX, edited by Ramón Gutiérrez, 95-185. Barcelona: Lunwerg Editores. 
Guzzo Decca, Maria Auxiliadora

1987 A vida fora fábricas: Cotidiano operário em São Paulo, 1920-1934. Rio de Janeiro: Paz e Terra.

Hitchcock, Henry-Russell

1971 Architecture: Nineteenth and Twentieth Centuries. Harmondsworth, Middlesex: Penguin. (Orig. pub. 1958.)

Hitchcock, Henry-Russell, and Philip Johnson

1995 The International Style. New York: W. W. Norton. (Orig. pub. 1932.)

Holston, James

1989 The Modernist City: An Anthropological Critique of Brasília. Chicago: The University of Chicago Press.

James, Daniel

1981 "Rationalisation and Working Class Response: The Context and Limits of Factory Floor Activity in Argentina." Journal of Latin American Studies 13, no. 2 (November): $375-402$.

Jencks, Charles

1973 Modern Movements in Architecture. Garden City: Anchor Books.

Kabat, Marina

1999 "El ojo del amo: Primeras inquietudes en torno al taylorismo en la Argentina, 1920-1930." Estudios del Trabajo 17:113-24.

Lampugnani, Vittorio Magnago

1986 Encyclopedia of 20th-Century Architecture. New York: Harry N. Abrams. (Orig. pub. 1964.)

Larson, Magali Sarfatti

1993 Behind the Postmodern Facade: Architectural Change in Late Twentieth-Century America. Berkeley, CA: University of California Press.

Liernur, Jorge Francisco

2000 Arquitectura en la Argentina del siglo XX: la construcción de la modernidad. Buenos Aires: Fondo Nacional de las Artes.

López Rangel, Rafael

1986 Diego Rivera y la arquitectura mexicana. Mexico, DF: Dirección General de Publicaciones y Medios.

Lorey, David E.

1990 "The Development of Engineering Expertise for Social and Economic Modernization in Mexico since 1929." In Society and Economy in Mexico, edited by James W. Wilkie, 71-102. Los Angeles: Latin American Center Publications, University of California at Los Angeles.

Ludwig, Armin K.

1980 Brasília's First Decade: A Study of its Urban Morphology and Urban Support Systems. Amherst, MA: International Area Studies Programs, University of Massachusetts at Amherst.

Luna Arroyo, Antonio

1973 Juan O'Gorman: Autobiografía, antología, juicios críticos y documentación exhaustiva sobre su obra. Mexico City: Cuadernos Populares de Pintura Mexicana Moderna.

Maddison, Angus

1995 Monitoring the World Economy 1820-1992. Paris: OECD. Méndez-Vigatá, Antonio E.

Méndez-Vigatá, Antonio E.

1997 "Politics and Architectural Language: Post-Revolutionary Regimes in Mexico and their Influence on Mexican Public Architecture, 1920-1952." In Modernity and the Architecture of Mexico, edited by Edward R. Burian, 61-89. Austin, TX:

Meyer, Jean University of Texas Press.

1991 "Revolution and Reconstruction in the 1920s." In Mexico Since Independence, edited by Leslie Bethell, 125-200. Cambridge: Cambridge University Press.

Midant, Jean-Paul, ed.

1996 Dictionnaire de l'architecture du XXe siècle. Paris: Institut Français d'Architecture.

Mijares Bracho, Carlos G.

1997 "The Architecture of Carlos Obregón Santacilia." In Modernity and the Architecture of Mexico, edited by Edward R. Burian, 151-61. Austin, TX: University of Texas Press. 
Muriel, Emanuel, ed.

1994 Contemporary Architects. New York: St. James Press. (Orig. pub. 1980.)

Myers, I. E.

1952 Arquitectura Moderna Mexicana. Mexico's Modern Architecture. New York: Architectural Book Publishing.

Noelle Merles, Louise

1997 "The Arcthitecture and Urbanism of Mario Pani: Creativity and Compromise." In Modernity and the Architecture of Mexico, edited by Edward R. Burian, 177-89. Austin, TX: University of Texas Press.

Ortiz, Federico F.

1984 "Resumen de la arquitectura argentina desde 1925 hasta 1950." In Documentos para una historia de la arquitectura argentina, edited by Marina Waisman, 191-94. Buenos Aires: Ediciones Summa.

Ortiz, Federico F., and Ramón Gutiérrez

1973 La arquitectura en la Argentina, 1930-1970. Special issue of Hogar y Arquitectura, no. 103.

Ortiz, Federico F., Juan C. Mantero, Ramón Gutiérrez, and Abelardo Levaggi

1968 La arquitectura del liberlismo en la Argentina. Buenos Aires: Editorial Sudamericana.

Paz, Octavio

1993 Essays on Mexican Art. New York: Harcourt Brace.

Pevsner, Nikolaus

1960 Pioneers of Modern Design: From William Morris to Walter Gropius. Harmondsworth, Middlesex: Penguin. (Orig. pub. 1936.)

Pfammatter, Ulrich

2000 The Making of the Modern Architect and Engineer. Berlin: Birkhäuser.

Placzek, Adolf K., ed.

1982 The Macmillan Encyclopedia of Architects. New York: Free Press.

Prebisch, Alberto

1927 "Carta abierta a Alejandro Christophersen." Martín Fierro (May). Reprinted in Alberto Prebisch: Una Vanguardia con Tradición, 178-79. Buenos Aires: CEDOAL. http: / / www.almargen.com.ar/sitio/seccion/arquitectura/prebisch/ disputa2.html

1932 “Instituto de Organização Racional do Trabalho de São Paulo." Revista de Organização Científica 1, no. 1 (January): 35-38.

Rodríguez Leirado, Eduardo

2001 "Alberto Prebisch y la modernidad argentina." Buenos Aires: Sitio al Margen. http://www.almargen.com.ar/sitio/seccion/arquitectura/prebisch/

Saenz Leme, Marisa

1978 A ideologia dos industriais brasileiros, 1919-1945. Petrópolis: Vozes.

Sharp, Dennis, ed.

1981 Sources of Modern Architecture: A Critical Bibliography. London and New York: Granada. (Orig. pub. 1967.)

Skidmore, Thomas E., and Peter H. Smith

1989 "Brazil: Development for Whom?" In Modern Latin America, edited by Thomas E. Skidmore and Peter H. Smith, 140-80. New York: Oxford University Press.

Smith, Clive Bamford

1967 Builders in the Sun: Five Mexican Architects. New York: Architectural Book Publishing. Sonderéguer, Pedro Conrado

1986 Arquitectura y modernidad en la Argentina. Buenos Aires: Centro de Estudios de la Sociedad Central de Arquitectos.

Tafuri, Manfredo

1976 Architecture and Utopia. Cambridge, MA: MIT Press.

Toca Fernández, Antonio

1997 "Juan Segura: The Origins of Modern Architecture in Mexico." In Modernity and the Architecture of Mexico, edited by Edward R. Burian, 163-76. Austin, TX: University of Texas Press.

Urwick, Lyndall

1956 The Golden Book of Management: A Historical Record of the Life and Work of Seventy Pioneers. London: Newman Neame Limited. 


\section{$32 \quad$ Latin American Research Review}

Vasconcelos, José

1963 A Mexican Ulysses. Bloomington, IN: Indiana University Press.

Warchavchik, Gregori

1965 "Acerca da Architetura Moderna." In Warchavchik e a introdução da nova arquitetura no Brasil: 1925 a 1940, edited by Geraldo Ferraz, 39-D. São Paulo: Museu de Arte de São Paulo. [Translated as "Apropos of Modern Architecture," on pp. 264 266.](Orig. pub. 1925.)

Weinstein, Barbara

1990 "The Industrialists, the State, and the Issues of Worker Training and Social Services in Brazil, 1930-1950." Hispanic American Historical Review 70, no. 3 (August): $379-404$.

Xavier, Alberto, Alfredo Britto, and Ana Luiza Nobre

1991 Arquitetura moderna no Rio de Janeiro. São Paulo: Editora Pini.

Zevi, Bruno

1994 The Modern Language of Architecture. New York: De Capo Press.(Orig. pub. 1973.) 
APPENDIX LEADING ARCHITECTS IN ARGENTINA, BRAZIL, AND MEXICO, 1890-1940

The lists of the ten most influential architects in Argentina, Brazil, and Mexico during the 1890-1940 period were generated from the analysis contained in four histories of architecture (Banham 1980; Benevolo 1977; Curtis 1996; Hitchcock 1971), and five encyclopedias (Lampugnani 1986; Midant 1996; Muriel 1994; Placzek 1982; Sharp 1981). I also relied on the encyclopedic dictionary found in Arquitectura latinoamericana en el siglo XX (Gutiérrez 1998b).

Argentina

\begin{tabular}{|c|c|c|c|}
\hline Architect & Lifespan & $\begin{array}{l}\text { Educational } \\
\text { Background }\end{array}$ & Citations \\
\hline Mario Roberto Álvarez & 1913- & $\begin{array}{l}\text { Architect, University } \\
\text { of Buenos Aires, UBA }\end{array}$ & e $f g h$ \\
\hline $\begin{array}{l}\text { Antonio Bonet } \\
\text { (Spanish-born) }\end{array}$ & 1913-1989 & $\begin{array}{l}\text { Architect, University } \\
\text { of Barcelona }\end{array}$ & $\mathrm{cfh}$ \\
\hline $\begin{array}{l}\text { Alejandro Christophersen } \\
\text { (Spanish-born) }\end{array}$ & 1866-1946 & $\begin{array}{l}\text { Architect, École } \\
\text { des Beaux-Arts }\end{array}$ & $\mathrm{fh}$ \\
\hline $\begin{array}{l}\text { Julián Jaime García } \\
\text { Núñez }\end{array}$ & $1875-1944$ & Apprenticed architect & $\mathrm{fh}$ \\
\hline Ángel Guido & $1896-1960$ & $\begin{array}{l}\text { Architect, University } \\
\text { of Córdoba }\end{array}$ & $\mathrm{fh}$ \\
\hline Jorge Ferrari Hardoy & 1914-1976 & Architect, UBA & $\mathrm{fh}$ \\
\hline $\begin{array}{l}\text { Juan Kronfuss } \\
\text { (Hungarian-born) }\end{array}$ & $1872-1944$ & $\begin{array}{l}\text { Engineer and architect, } \\
\text { Technische Hochschule, } \\
\text { Munich }\end{array}$ & $\mathrm{fh}$ \\
\hline Martín Noel & $1888-1963$ & $\begin{array}{l}\text { Architect, École } \\
\text { des Beaux-Arts }\end{array}$ & $\mathrm{fh}$ \\
\hline Alberto Prebisch & 1899-1970 & $\begin{array}{l}\text { Architect and } \\
\text { mathematician, UBA }\end{array}$ & $\mathrm{f}$ \\
\hline Antonio Ubaldo Vilar & $1888-1966$ & Architect, UBA & $\mathrm{fh}$ \\
\hline Brazil & & & \\
\hline
\end{tabular}

\begin{tabular}{|c|c|c|c|}
\hline Architect & Lifespan & $\begin{array}{l}\text { Educational } \\
\text { Background }\end{array}$ & Citations \\
\hline Oswaldo Bratke & 1907-1997 & $\begin{array}{l}\text { Engineer and architect, } \\
\text { University of Mackenzie }\end{array}$ & $\mathrm{fh}$ \\
\hline Lúcio Costa & 1902-1998 & $\begin{array}{l}\text { Architect, Escola } \\
\text { Nacional de Belas Artes, } \\
\text { ENBA, Rio }\end{array}$ & $b c e g f h$ \\
\hline Rino Levi & $1901-1965$ & $\begin{array}{l}\text { Architect, Milan and } \\
\text { Rome }\end{array}$ & $\mathrm{fgh}$ \\
\hline
\end{tabular}




\begin{tabular}{|c|c|c|c|}
\hline Jorge Moreira & 1904-1992 & Architect, ENBA Rio & $\mathrm{fgh}$ \\
\hline Oscar Niemeyer & $1907-$ & Architect, ENBA Rio & $\begin{array}{l}\text { bcde } \\
\text { fghi }\end{array}$ \\
\hline Affonso Eduardo Reidy & 1909-1964 & Architect, ENBA Rio & $b c d f g h$ \\
\hline Marcelo Roberto & $1908-1964$ & Architect, ENBA Rio & $\mathrm{bdfgh}$ \\
\hline Milton Roberto & 1914-1953 & Architect, ENBA Rio & $\mathrm{d} f \mathrm{gh}$ \\
\hline Mauricio Roberto & 1921-1997 & Architect, ENBA Rio & $\mathrm{bdfgh}$ \\
\hline $\begin{array}{l}\text { Gregori Warchavchik } \\
\text { (Russian-born) }\end{array}$ & 1896-1972 & $\begin{array}{l}\text { Architect, Academia } \\
\text { de Belle Arti, Rome }\end{array}$ & ef $g h$ \\
\hline \multicolumn{4}{|l|}{ Mexico } \\
\hline Architect & Lifespan & $\begin{array}{l}\text { Educational } \\
\text { Background }\end{array}$ & Citations \\
\hline Luis Barragán & $1902-1988$ & $\begin{array}{l}\text { Civil engineer, Escuela } \\
\text { Libre de Ingenieros, } \\
\text { Guadalajara }\end{array}$ & cef $g h$ \\
\hline $\begin{array}{l}\text { Adamo Boari } \\
\text { (Italian-born) }\end{array}$ & $1865-1928$ & Architect & $\mathrm{h}$ \\
\hline $\begin{array}{l}\text { Enrique de la Mora } \\
\text { y Palomar }\end{array}$ & $1907-1978$ & $\begin{array}{l}\text { Architect, Universidad } \\
\text { Nacional Autónoma } \\
\text { de México (UNAM) }\end{array}$ & f \\
\hline Carlos Obregón Santacilia & $1896-1961$ & Architect, UNAM & \\
\hline Juan O'Gorman & 1905-1982 & Architect, UNAM & $\begin{array}{l}\text { cdef } \\
\text { ghi }\end{array}$ \\
\hline Mario Pani & 1911-1993 & $\begin{array}{l}\text { Architect, École } \\
\text { des Beaux-Arts }\end{array}$ & $\mathrm{fgh}$ \\
\hline Juan Segura Gutiérrez & 1898-1989 & Architect, UNAM & $\mathrm{f}$ \\
\hline Francisco Serrano & 1900-1982 & $\begin{array}{l}\text { Engineer and architect, } \\
\text { UNAM }\end{array}$ & $\mathrm{f}$ \\
\hline José Villagrán García & 1901-1992 & Architect, UNAM & ef $g h$ \\
\hline $\begin{array}{l}\text { Enrique Yáñez } \\
\text { de la Fuente }\end{array}$ & 1908-1992 & Architect, UNAM & $\mathrm{f}$ \\
\hline
\end{tabular}

NOTES:

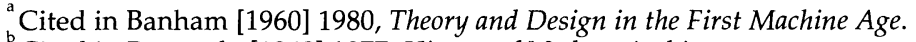

${ }^{\mathrm{b}}$ Cited in Benevolo [1960] 1977, History of Modern Architecture.

'Cited in Curtis [1982] 1996, Modern Architecture since 1900.

${ }^{d}$ Cited in Hitchcock [1958] 1971, Architecture: Nineteenth and Twentieth Centuries.

e Entry in Lampugnani [1964] 1986, Encyclopedia of 20th-Century Architecture.

'Entry in Midant ed. 1996, Dictionnaire de l'architecture du XXe siècle.

${ }^{8}$ Entry in Muriel ed. [1980] 1994, Contemporary Architects.

${ }^{\mathrm{h}}$ Entry in Placzek ed. 1982, The MacMillan Encyclopedia of Architects.

i Entry in Sharp ed. [1967] 1981, Sources of Modern Architecture: A Critical Bibliography. 